\title{
Esophageal bronchogenic cyst: an uncommon cause of dysphagia in adults. Case report and literature review
}

\author{
Quiste broncogénico esofágico: una causa poco común de disfagia en adultos. Reporte \\ de caso y revisión de la literatura
}

Ana P. Ceniceros-Cabrales* and Patricio Sánchez-Fernández

Gastric Surgery Department, Specialty Hospital, Centro Médico Nacional Siglo XXI, Instituto Mexicano del Seguro Social, Mexico City, Mexico

\begin{abstract}
Background: Bronchogenic cysts result from abnormal budding of the primitive tracheobronchial tube and are rare congenital cystic lesions. The location of the cyst depends on the embryological stage of abnormal budding. Although periesophageal bronchogenic cysts have been frequently reported, a completely intramural cyst is very rare. Clinical case: $A$ 42-year-old female patient, a three-month course with retrosternal pain associated with food intake, accompanied by intermittent dysphagia to solids. Esophagogram, high resolution thoracic tomography and endoscopic ultrasound are performed, concluding a probable esophageal bronchogenic cyst. Resection is performed by video-assisted thoracic surgery, without complications. Patient presents with adequate evolution and complete remission of the symptomatology. Conclusion: Bronchogenic cysts of the esophageal wall are extremely uncommon lesions. Its surgical treatment is indicated to be symptomatic; video-assisted thoracoscopic surgery resection is of choice, with excellent long-term results and minimal morbidity.
\end{abstract}

KEY WORDS: Bronchogenic cyst. Esophagus. Dysphagia. Video-assisted thoracic surgery.

\section{Resumen}

Antecedentes: Los quistes broncogénicos son lesiones cong-énitas raras que resultan de brotes anormales del tubo traqueobronquial primitivo. La localización del quiste depende de la etapa embriológica del brote anormal. Aunque los quistes broncogénicos periesofágicos han sido frecuentemente reportados, un quiste completamente intramural es muy raro. Caso clínico: Mujer de 42 años con cuadro de 3 meses de evolución, con dolor retroesternal asociado a la ingestión de alimentos, acompañado de disfagia intermitente a sólidos. Se realiza esofagograma, tomografía de tórax de alta resolución y ultrasonido endoscópico, que concluyen probable quiste broncogénico esofágico. Se realiza resección por cirugía torácica videoasistida, sin complicaciones. La paciente cursa con adecuada evolución y remisión completa de la sintomatología. Conclusión: Los quistes broncogénicos de la pared esofágica son lesiones extremadamente poco comunes. Está indicado su tratamiento quirúrgico al ser sintomáticos; es de elección la resección por cirugía torácica videoasistida, con excelentes resultados a largo plazo y mínima morbilidad.

PALABRAS CLAVE: Quiste broncogénico. Esófago. Disfagia. Cirugía torácica videoasistida.

\footnotetext{
Correspondence:

*Ana Paula Ceniceros-Cabrales

Av. Cuauhtémoc, 330

C.P. 06725, Ciudad de México, México

E-mail: anapaucc@ hotmail.com
}

Date of reception: 20-07-2017

Date of acceptance: 27-03-2018

DOI: $10.24875 /$ CIRUE.M18000027
Cir Cir. 2018;86:168-171

Contents available at PubMed www.cirugiaycirujanos.com 


\section{Background}

Bronchogenic cysts are rare congenital lesions that result from abnormal budding of the primitive tracheobronchial tube 1 . The location of the cyst depends on abnormal budding embryological stage ${ }^{2}$.

Approximately $36-90 \%$ of bronchogenic cysts occur in the mediastinum, and most of the remaining cysts involve the lung parenchyma ${ }^{3}$. Esophageal bronchogenic cysts are rare; paraesophageal cysts are the most typically reported, and completely intramural cysts are quite rare. Intramural esophageal bronchogenic cysts have only been described in 23 adult cases since $1981^{4}$.

Most patients are newborns or infants at presentation. The symptoms are usually caused by intrathoracic structures compression, with predominant respiratory problems. Primary symptoms consist of retrosternal pain, cough, dyspnea or fever ${ }^{5}$.

As for the treatment of esophageal bronchogenic cysts, complete surgical resection is recommended by means of thoracotomy or video-assisted thoracic surgery. Some authors recommend it even when patients are asymptomatic, due to later complications such as infection, rupture, intracystic hemorrhage or carcinomatous changes ${ }^{6}$.

\section{Objective}

To describe a rare case of a bronchogenic cyst of the esophageal wall diagnosed in adulthood, which was treated with video-assisted thoracic surgery resection, as well as to perform a literature review.

\section{Clinical case}

This is the case of a 42-year-old woman. She denied having any chronic-degenerative disease and had a surgical history of two cesarean sections and bilateral tubal occlusion, with no other data of relevance. At admission, she had a 3-month history of retrosternal pain associated with food intake, accompanied by intermittent dysphagia to solids.

As part of her diagnostic workup, she underwent an esophagography, high-resolution chest tomography and endoscopic ultrasound. The esophagography showed extrinsic compression in the middle third of the esophagus (Fig. 1). Chest tomography documented a mass attached at the middle third of the esophagus, which pushed the trachea and aorta (Fig. 2). Endoscopic ultrasound reported a cystic lesion at between 26 and $31 \mathrm{~cm}$ from the dental arch, which

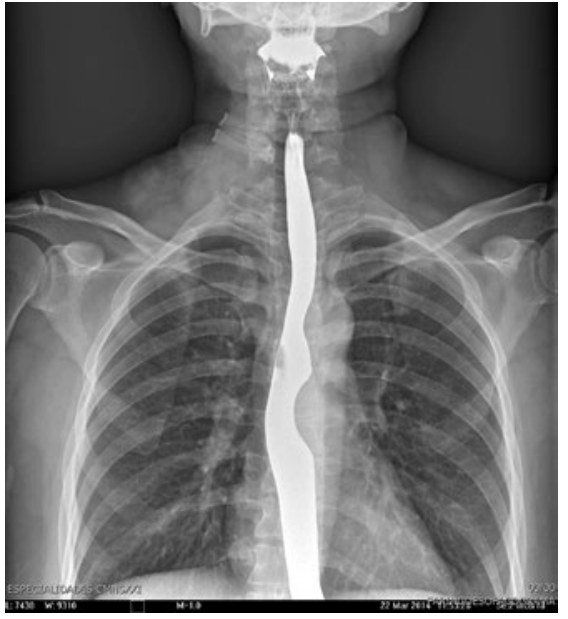

Figure 1. Esophagography showing extrinsic compression in the middle third of esophagus.

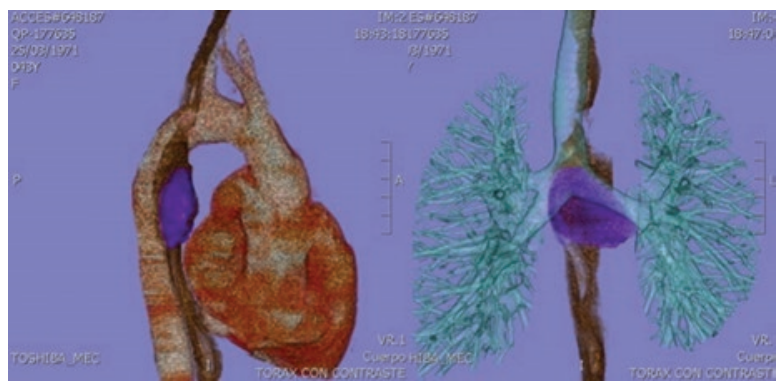

Figure 2. High-resolution chest tomography reconstruction, which shows a mass in the middle third of esophagus, which pushes the trachea and aorta.

measured $39 \times 30 \mathrm{~mm}$ in diameter, with anechoic, discretely turbid content, arising from the esophagus wall and growing inwards covered by normal esophageal mucosa and outwards pushing the trachea and aorta, as well as an adenopathy in the sub-carinal region. Differential diagnosis was probable bronchogenic cyst vs. duplication cyst (Fig. 3).

Performing a resection by video-assisted thoracic surgery was decided, which revealed a $30 \times 30 \mathrm{~mm}$ lesion on the left lateral side of the esophagus, at the middle third (Fig. 4), with histopathological report of bronchogenic cyst (Fig. 5). The patient had an adequate postsurgical evolution, with incidence of pneumothorax after removal of the endopleural catheter, which was replaced and then successfully withdrawn. The patient was discharged home in appropriate conditions and with complete symptom remission.

\section{Discussion}

Bronchogenic cysts are bronchopulmonary foregut abnormalities that usually occur along the tracheobronchial 


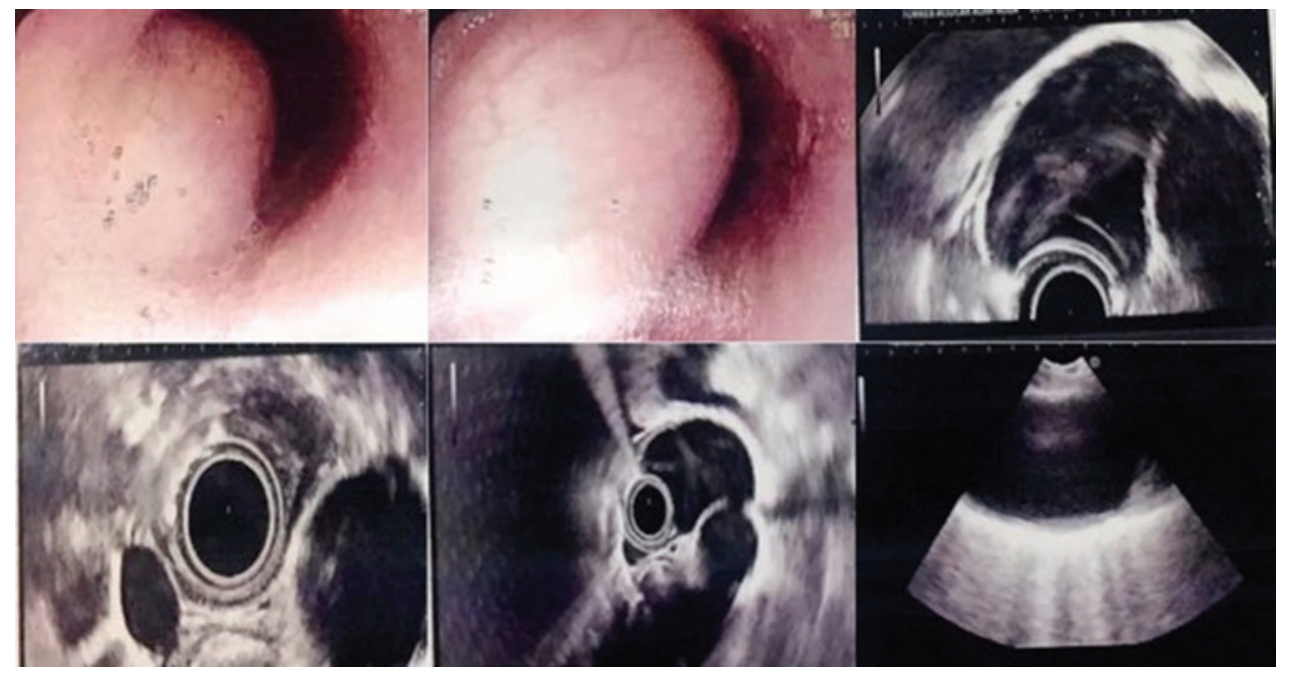

Figure 3. Endoscopic ultrasound that reported a cystic lesion at between 26 and $31 \mathrm{~cm}$ of the dental arch, of $39 \times 30 \mathrm{~mm}$ in diameter, with anechoic content, which arises from the esophageal wall and grows inwards covered by normal esophageal mucosa and outwards pushing the trachea and aorta.

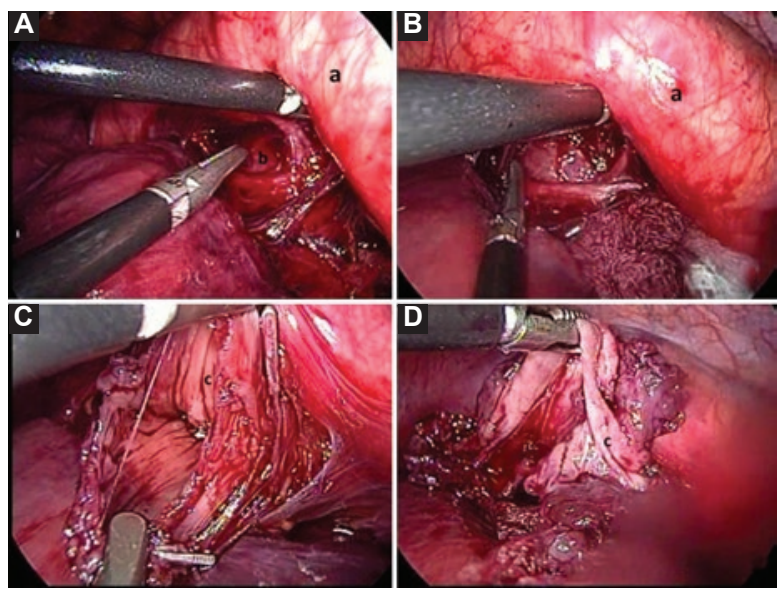

Figure 4. A and B: bronchogenic cyst dissection from adjacent structures. C: opening of the cyst, after aspiration of its content. D: the wall of the already-dissected cyst is shown. a: thoracic aorta, b: bronchogenic cyst, c: bronchogenic cyst wall.

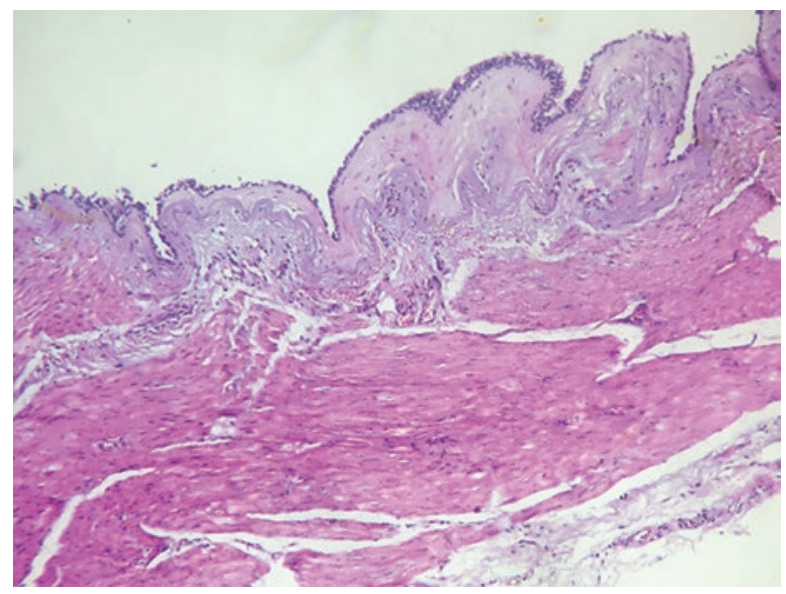

Figure 5. Histological image showing the respiratory epithelium that lined the cyst interior (staining with eosin and hematoxylin, 40x amplification). tree in the mediastinum². They can be located in the paratracheal, carinal or hilar region. Esophageal bronchogenic cysts develop when abnormal budding occurs in the laryngotracheal groove after the third week of gestation $^{2,7}$.

Histologically, bronchogenic cysts are characterized by the presence of ciliated cylindrical epithelium and various components of smooth muscle, bronchial gland, cartilage and even pulmonary alveoli in the cyst wall, depending on the stage of gestation at which abnormal budding occurs ${ }^{2}$.

When present, symptoms are usually caused by compression of the surrounding structures or by complications related to the cyst ${ }^{8}$. The most common complications are intracystic hemorrhage, infection, inflammation, ulceration of the cyst, and rupture or perforation of the cyst in the tracheobronchial tree, pericardium or pleura. A mediastinal cystic mass of 3-4 cm adjacent to the esophagus that occurs with dysphagia and chest pain is highly suggestive of a bronchogenic cyst ${ }^{2}$.

Different imaging techniques help locate the anomaly and detect any associated lesion. Postero-anterior and lateral chest X-ray, which is the primary diagnostic modality, can demonstrate the location of the cyst, its size and contours, and especially can show air-fluid levels in the cyst. Contrast esophagography can show if there is communication between the cyst and the esophagus, or reveal only extrinsic smooth compression and displacement of the esophagus. Computed tomography is useful to evaluate the cystic nature of the mass, showing an almost watery homogeneous 
density; it can indicate the exact location of the mass and its relationship with other thoracic structures ${ }^{9}$. However, if the cyst is infected or has protein and calcium high content, its density may fall within the range of solid tissue, which increases diagnostic uncertainty ${ }^{10}$. Definitive diagnosis is established after surgical excision with histological confirmation ${ }^{11}$.

Magnetic resonance imaging is sensitive to detect tissue filled with fluid. However, many bronchogenic cysts contain large amounts of protein material, thus producing hyperintense T1-weighted images, which makes it difficult to differentiate fatty lesions. Endoscopy is carried out to rule out the presence of malignancy ${ }^{10}$. Endoscopic ultrasound is useful for diagnosing intramural esophageal bronchogenic cysts, through a clear delimitation of the submucosal location of the cyst ${ }^{6}$.

The treatment of bronchogenic cysts remains controversial. If the cyst is symptomatic, conventional or thoracoscopic enucleation can be performed. The purpose of surgery is diagnosis, resection and prevention of complications. Video-assisted thoracoscopic surgery is a less invasive option, but with a complication rate of $10-30 \%^{4,12}$. Alternatives to surgery include transesophageal needle aspiration, and even a successful extirpation by transoral endoscopic resection for a cyst located in the esophageal wall has been described ${ }^{13-15}$. Radical surgical resection of the bronchogenic cyst, regardless of the surgical method, offers satisfactory results, without long-term recurrence ${ }^{2}$.

\section{Conclusion}

Bronchogenic cysts of the esophageal wall are extremely rare lesions. When symptomatic, surgical treatment is indicated, with video-assisted thoracic surgery resection being the choice, with excellent long-term results and minimal morbidity.

\section{Ethical responsibilities}

Protection of people and animals. The authors declare that the procedures followed were in adherence to the ethical standards of the responsible human experimentation committee and in accordance to the World Medical Association and the Declaration of Helsinki.
Confidentiality of data. The authors declare having followed the protocols of their work center on the publication of patient data.

Right to privacy and informed consent. The authors have obtained informed consent from the patients and/or subjects referred to in the article. This document is in the possession of the corresponding author.

\section{Conflicts of interest}

The authors declare not having any conflicts of interest.

\section{Funding}

The authors declare not having received any funding to carry out this work.

\section{References}

1. St-Georges R, Deslauriers J, Duranceau A, Vaillancourt R, Deschamps $\mathrm{C}$, Beauchamp $\mathrm{G}$, et al. Clinical spectrum of bronchogenic cysts of the mediastinum and lung in the adult. Ann Thorac Surg. 1991;52:6-13.

2. Ko S, Hsieh M, Lin J, Huang C, Li C, Cheung Y, et al. Bronchogenic cyst of the esophagus: clinical and imaging features of seven cases. Clin Imag. 2006; 30:309-14.

3. Berrocal T, Madrid C, Novo S, Gutiérrez J, Arjonilla A, Gómez-León N. Congenital anomalies of the tracheobronchial tree, lung, and mediastinum: embryology, radiology, and pathology. Radiographics. 2004;24:27.

4. Turkyilmaz A, Eroglu A, Subasi M, Findik G. Intramural esophageal bronchogenic cysts: a review of the literature. Dis Esophagus. 2007; 20:461-5.

5. Nobuhara K, Gorski Y, Quaglia M, Shamberger R. Bronchogenic cysts and esophageal duplications: common origins and treatment. J Pediatr Surg. 1997;37:1408-13.

6. Han $C$, Lin R, Yu J, Zhang Q, Zhang $Y$, Liu J, et al. A case report of esophageal bronchogenic cyst and review of the literature with an emphasis on endoscopic ultrasonography appearance. Medicine. 2016; 95:11.

7. Westerterp M, Van den Berg, J, Van Lanschot J, Fockens P. Intramural bronchogenic cysts mimicking solid tumors. Endoscopy. 2004;36:1119-22.

8. Altieri M, Zheng R, Pryor A, Heimann A, Ahn S, Telem D. Esophageal bronchogenic cyst and review of the literature. Surg Endosc. 2015; 29:3010-5.

9. Yang X, Partanen K, Seppa A, Berg E, Pasanen P. Paraesophageal bonchogenic cyst in adult: can it be differentiated from intramural esophageal cyst by different imagenings? Clinical Imagin. 1994;18:68-71

10. Lim L, Ho K, Goh P. Preoperative diagnosis of a paraesophageal bronchogenic cyst using endosonography. Ann Thorac Surg. 2002;73:633-5.

11. Chuang $\mathrm{K}$, Huang $\mathrm{T}$, Cheng $\mathrm{Y}$, Chen J, Tzao $\mathrm{C}$, Chang $\mathrm{H}$, et al. Esophageal bronchogenic cyst: a rare entity. Z Gastroenterol. 2007; 45:958-60.

12. Chafik A, Benjelloun A, Qassif H, El Fikri A, El Barni R, Zrara I. Intramural esophageal bronchogenic cysts. Asian Cardiovascular \& Thoracic Annals. 2011;19:69-71.

13. Watson DI, Britten-Jones R. Thoracoscopic excision of bronchogenic cyst of the esophagus. Surg Endosc. 1995;9:824-5.

14. Sashiyama H, Miyazaki S, Okazaki Y, Kaiho T, Nakajima Y, Hoshino $T$, et al. Esophageal bronchogenic cyst successfully excised by endoscopic mucosal resection. Gastrointest Endosc. 2002:56:141-5.

15. Martinod E, Pons F, Azorín J, Mouroux J, Dahan M, Faillon JM, et al. Thoracoscopic excision of mediastinal bronchogenic cysts: results in 20 cases. Ann Thorac Surg. 2000;69:1525-8. 